which should facilitate investigations of resistance to warfarin in the field.

J. H. Greaves

Priscilla Ayres

Infestation Control Laboratory,

Ministry of Agriculture, Fisheries and Food,

Hook Rise South, Tolworth,

Surbiton, Surrey.

Received July 17, 1967.

${ }^{2}$ Boyle, C. M., Nature, 188, 517 (1960)

2 Lund, M., Nature, 203, 778 (1964).

- Drummond, D. C.. and Bentley, E. W., Report of the International Conference on Rodents and Rodenticides (E.P.P.O. Paris, 1967)

- O'Reilly, R. A., and Aggeler, P. M., Fed. Proc., 24, 1266 (1965).

\section{Indication of Cyclic Reproductive Activity in Abyssal Organisms}

The difficulty in sampling the sea floor at depths greater than $2,000 \mathrm{~m}$ (ref. 1), where the abyssal zone is believed to start $^{2}$, is so great that even today there are not many samples. The yield in specimens from the samples which have been taken is low for any given species of animal and it is seldom that one species has been repeatedly taken. These factors have combined to permit few observations on the biology of any ono species. In general, so few ovigerous or gravid specimens of deep sea isopods have been taken that Wolff ${ }^{3}$ has reasoned that gravid specimens hide in the mud, thus avoiding capture, or that the breeding period is short and occurs once every second or third year. An example of the absence of gravid female specimens can be found in the report by Menzies ${ }^{4}$ on 123 abyssal spocies of marine isopods representing 447 specimens. In six cases gravid specimens were reported.

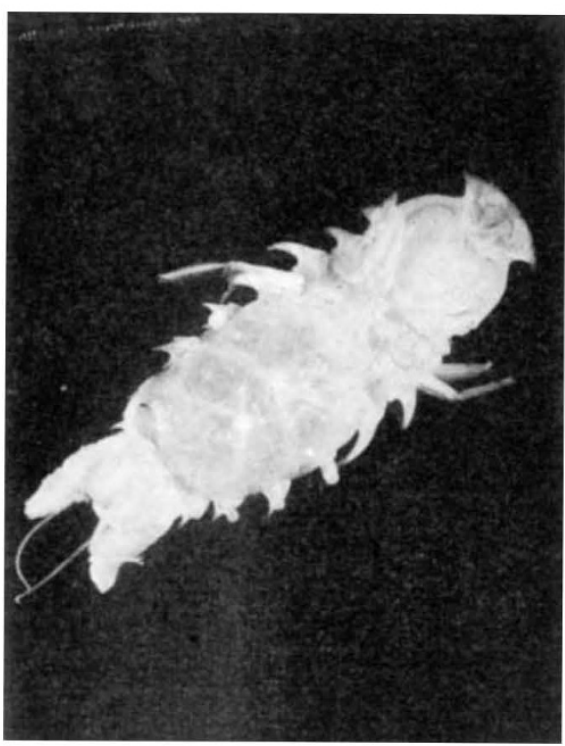
Fig. 2. Ovigerous female of Storthyngura birsteini Menzies, 1962 (ref. 4).
(Length $18 \mathrm{~mm}$, maximum wisth $8 \mathrm{~mm}$ ) from Scotia Sea, depth, 3,731$3.804 \mathrm{~m}$.

endogenous solar and lunar rhythmicity persists in organisms when they are subjected to constant conditions in the laboratory ${ }^{5}$. We consider it reasonable to suppose that deep sea organisms might show persistent reproductive eycles in the absence of seasonal environmental changes which might reflect their origin from shallow water organisms. The data which we present for species of the genus Storthyngura support this view (Fig. 1,

\begin{tabular}{|c|c|c|c|c|c|c|c|c|c|}
\hline \multirow{5}{*}{$\begin{array}{c}\text { No. } \\
1\end{array}$} & Species & $\begin{array}{l}\text { Exped. } \\
\text { Cr. and Sta. No. }\end{array}$ & Depth (m) & Date & Male & Female & $\begin{array}{l}\text { Ovigerous } \\
\text { female }\end{array}$ & $\begin{array}{l}\text { Gravidity } \\
\text { (per cent) }\end{array}$ & \multirow{9}{*}{ 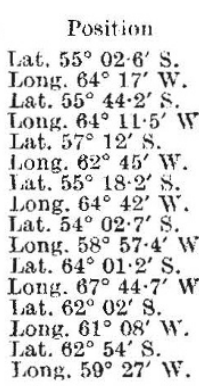 } \\
\hline & S. birsteini Monzies & VEMA $15-114$ & 1,737 & March 14, 1959 & 1 & 5 & 0 & $\theta$ & \\
\hline & S. birsteini Menzies & VEMA $15-118$ & 3,776 & March 16,1959 & 0 & 2 & 0 & 0 & \\
\hline & s. birsteini Menzies & ELT 4-126 & $3,731-3,804$ & July 29,1962 & 2 & 5 & 4 & $5 i$ & \\
\hline & S. birsteini Menzies & ELT 11 973 & $1,920-2,210$ & Feb. 11, 1964 & 0 & 16 & 0 & 0 & \\
\hline \multirow[t]{2}{*}{2} & S. scotia* & ELT 6-350 & 2,450 & Dec. 4,1962 & 3 & 1 & 0 & 0 & \\
\hline & S. scotia* & HLT 5-268 & $2,761-2,816$ & Oct. 20,1962 & 0 & 4 & 1 & 25 & \\
\hline \multirow[t]{2}{*}{3} & S. robustissima Monod & EI'T' 4-138 & $1,290-1,485$ & Ang. 8, 1962 & 3 & 6 & 1 & 11 & \\
\hline & S. robustissima Monod & FL'T 6-432 & $884-935$ & Jan. 7,1963 & 1 & 1 & 0 & 0 & \\
\hline
\end{tabular}

Percentage of gravidity represents the percentage of ovigerous females in the total number of males and females in a population sample.

* Manuscript names used by the authors.

There are no known seasonal environmental changes in the deep sea comparable with the magnitude of seasonal change at the sea surface. It might be reasonable to suppose therefore that unusual breeding conditions exist. It has, however, been convineingly demonstrated that

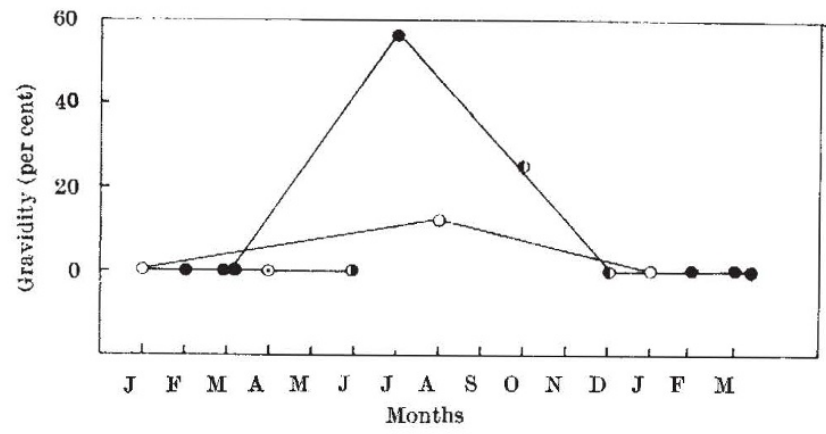
Fig. 1. Breeding activity in sub-Antarctic abyssal species of Stor
thyngura (Crustacea, Isopoda). robustissima; $\odot$, s. eltaniae* and sepigia*; O, S. triplispinosa. (Species with an asterisk are manuscript names used by the authors.)
Table 1). A gravid female is shown in Fig. 2. Quite obviously the data are necessarily scanty. They deny neither of Wolff's" speculations, but instead suggest another mechanism-seasonal breeding cycles-comparable with those known for shallow water animals.

This research was supported by a grant from the USARP, National Science F'oundation.

\section{R. Y. GEOROF*}

R. J. MENZIES*

Duke University Marine Laboratory,

Beaufort, North Carolina.

Department of Zoology,

Duke University,

Durham, North Carolina.

Received May 22, 1967.

* Present address: Department of Occanography, Florida State University, Tallahassee, Floricla.

${ }^{1}$ Menzies, R. J., Intern. Rev. Ges. Hydrobiol., 48, 185 (1963).

2 Gkman. S., Zoogeography of the Sea, 415 (Sidgwick and Jackson, T.tet. London, 1953).

${ }^{3}$ Wolff, T., Galathea Rep., 6, 219 (1962).

- Menzies, R. J., Abyssal Crustacea, Vema Res. Ser. 1, 80 (196:2).

- Brown, jun., H. A. Webb, H. M., and Bennet, M. F. Pror. L's Nat, Actur. Sci., 41, 93 (1955) 